\title{
ANTECEDENTS AND CONSEQUENCES OF SUCCESSFUL IMPLEMENTATION OF ACCRUAL BASED GOVERNMENT ACCOUNTING SYSTEM IN CENTRAL GOVERNMENT
}

\author{
Amrizal $^{1} \square$, Hamilah $2 \square$, Afiifun Marjaana ${ }^{3} \square$ \\ 1, 2,3 Sekolah Tinggi Ilmu Ekonomi Y.A.I Jakarta, Indonesia.
}
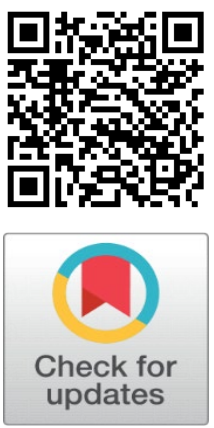

Received 5 November 2021

Accepted 16 December 2021

Published 31 December 2021

\section{CorrespondingAuthor}

Amrizal,

amrizal@stie-yai.ac.id

DOI

10.29121/granthaalayah.v9.i12.2021 .4362

Funding: This research received no specific grant from any funding agency in the public, commercial, or not-for-profit sectors.

Copyright: (C) 2021 The Author(s). This is an open access article distributed under the terms of the Creative Commons Attribution License, which permits unrestricted use, distribution, and reproduction in any medium, provided the original author and source are credited.

\section{ABSTRACT}

This research aims to test the influence of Human Resources Competency, Leadership Commitment, Information Technology Support, Internal Control over Financial Reporting on the Quality of Financial Statements of Ministries and Non-Ministries Government Indonesia, with intervening variables Implementation of Accrual-based Government Accounting Standards (Empirical Studies on Ministries and Non-Ministries Government Indonesia). The population in this study was Fifty-Three Ministries and NonMinistries Government Indonesia, which obtained a fair opinion without exception on examining financial statements by the Indonesian Audit Board for five years, from 2015 to 2019. Sampling techniques using the purposive sampling method as many as 212 questionnaires are disseminated to 53 Ministries and Non-Ministries Government Indonesia who obtained fair opinion without exception by Indonesian Audit Board. The model used in this research is SEM Analyst using LISREL 8.8 application.

The study results showed the Leadership Commitment had a positive but insignificant effect on the Implementation of accrual-based and Information Technology Support has a positive but insignificant impact on the Quality of Financial Statements of Ministries and institutions. Leadership is competency needed for communication between leaders in delivering accrual information and an accounting system that does not provide automatic accrual adjustment. The researchers expected that the central government could create an accounting system that automatically identifies accrual data and cuts off accrual transactions.

Keywords: Aaccrual-Based Government Accounting Standards, Quality of Financial Statements, Human Resources Competency, Aleadership Commitment, Informationa Technologya Support, Internal Control Over Financial Reporting

\section{INTRODUCTION}

Based on the mandate of Law No. 1 of 2004 on State Reform and Law No. 17 of 2003 and PP No. 71 of 2010 on Government Accounting Standards stipulated in the preparation of Financial Statements since 2015 must use accrual-basis or Accrual Basis. Based on the Summary of Examination Results (IHPS) Audit Board of the Republic of Indonesia in 2016, the impact of accrual-based accounting implementation in 2015 is a decrease in the quality of financial statements WTP (Fair Without Exception) by 5\% from 2014. The presentation of accounts on the financial statements is still weak. WTP opinion on LKKL until 2019 continues to increase to $97 \%$ based on the Audit Board of the Republic of Indonesia IHPS Semester I year 2020, but accrual recording is still weak.

Herwiyanti et al. (2017) research shows that accrual-based accounting difficulties are the choice of assessment, recognition, and reporting. There are 
risks of government rights and obligations not recorded due to accrual basis accounting practices and Accrual adjustments done at the end of the period. Herwiyanti et al. (2017) suggested that the many choices for assessment, recognition and reporting can cause pressure to obtain information from the author and users of financial statements. According to Budiman, Slamet (2016),, the commitment of leaders and strong support from the leadership are the critical success of changes in the accounting system of the public sector. Leadership is a person's ability to influence, activate, and make people or groups achieve a successful and effective organization.

According to Ritonga (2010) and Halim (2012), the leadership's commitment significantly influences the success of accrual-based accounting implementation. Therefore, The Leadership Commitment is an antecedent of the success of accrualbased Accounting System Implementation.

Human Resources Competency (HR) affects the successful implementation of accrual-based accounting systems. According to Najati et al. (2016),, the resistance to a successful implementation of accrual-based accounting is the complexity of accrual base accounting, leading to rejection of the application. Research byNajati et al. (2016), Kristyono et al. (2013), Ardiansyah (2013), Nufus (2014)., Surya (2015), Yogiswara, I Wayan Gede Farma Putra and Ariyanto (2015). , Sukadana and Mimba, (2015) stated that the quality of Human Resources positively influences the readiness and successful implementation of accrual basis accounting system. Waspodo et al. (2017) research also stated the same with previous research, namely Human Resource Competency is antecedent of the successful implementation of the accrual-based accounting system. The use of reliable information technology can support the successful management of accrual-based accounting system data. Based on the research of Pattiasina (2019), Budiman, Slamet (2016),, Eriotis et al. (2011), Puspitasari, Evita et al. (2016), technology information supports the successful Implementation of Accrual-Based Accounting System. Therefore, Technology Support is an antecedent of successful Implementation of an Accrual-Based Accounting System.

Internal control over financial reporting ensures that organizational objectives are executed effectively and efficiently, reliable financial statements, safeguarding state assets, and organizational compliance with applicable laws and regulations. Internal Control over Financial Reporting (ICOFR) is a control specifically designed to provide adequate assurance that financial statements are reliably crafted and follow accrual basis accounting standards. According to Alvin Arens et al. (2004:432), internal control abuses can increase financial statements' misstatements. Based on Pattiasina (2019), The application of internal control positively influences the successful application of accrual basis accounting in the entity. Therefore, the Internal Control System is the main foundation for achieving the successful implementation of accrual-based accounting.

Qualitative characteristic is a normative requirement in accounting information in order for financial statements to meet their objectives. Qualitative characteristics are described in Government Regulation's conceptual framework on Government Accounting Standards No. 71 of 2010. Pamungkas (2012); Agustiawan et al. (2016); Christanti and Dianne (2013) ; Mardiana, Rizki, and Heru Fahlevi (2017) found the implementation of accrual-based government accounting standards had a positive effect on the accountability of the quality of financial statements. Therefore, accrual-based government accounting standards are antecedents of the quality of accrual-based financial statements. 
Accrual-based financial statements have a variety of assessments and recognitions, and reporting. Therefore, Human Resources must have the competence and understand the principles of accrual-based financial statements. It is getting from education and training and skills in carrying out the task of preparing financial statements. Based on Yusnita (2017) ; Karsana (2017) ; Agung, tut Agung and Madiguna (2018) ; Mardiana, Rizki, and Heru Fahlevi (2017) Human Resources competency affects the quality of accrual-based financial statements. Human resources competency is an antecedent quality of accrual-based financial statements.

The complexity of accrual-based financial statements requires leadership commitment. Based on Irawan (2015), the weakness of a leader's responsibilities can cause the weak preparation of financial statements. Based on the study of Tut Madiguna and Gayatri (2018), Lubis and Saripudin. (2017), Yusnita (2017) , Fitriani (2017) , the quality of financial statements significantly influences by the leadership's commitment. Therefore, the leadership commitment is antecedent of the quality of accrual-based financial statements.

Information technology supports the reliability and timeliness of government financial report submission. Winidyaningrum (2010).proved that the influences of the utilization of information technology affect positive and significant to the reliability and timely financial of local governments. Aryani (2013) confirms that the quality of financial statements is affected simultaneously and partially by utilizing information technology. Therefore, Technology Support is an antecedent of the quality of accrual-based financial statements.

Another factor that affects the quality of financial statements is internal control. Based on Government Regulation No. 60 of 2018, Internal control systems ensure that organizational objectives are executed effectively and efficiently, reliability of financial reporting, safeguarding state assets, and compliance with laws and regulations. Karsana (2017) ; Agung, Tut Madiguna and Gayatri (2018), Yusnita (2017) ; Fitriani (2017), ; Agustiawan and Ni (2016); Christanti (2013) ; Mardiana, Rizki and Heru Fahlevi (2017); Lashgari et al. (2015)Fransiska et al.(2015) ; Aryani (2013), empirically proves that the value and quality of financial statements are positively and significantly influenced by internal control. Therefore, Internal Control over Financial Reporting is an antecedent of the quality of accrual-based financial statements.

This research-based is on Rasyidah and Hasyim (2017) study on the Influence of Information Technology Utilization, Human Resource Competency, on the Quality of Local Government Financial Statements with Intervening Variables of AccrualBased Government Accounting Standards. The difference with previous research is that the Leadership Commitment and Internal Control over Financial Reporting variables add to independent variables. The researcher did the study at Ministry and Central Government Institutions, where there has been no similar research with respondents compiling financial statements of the Ministry and Central Government Institutions.

\section{LITERATUREAREVIEW}

\section{AgencyaTheory}

Agency theory is a contractual relationship between principals and agents. Agency Theory discusses principals who delegate work and authority to other parties (agents). Agents morally have a responsibility to maximize profits to the owner or principal. On the other hand, the agent is interested in maximizing his welfare. Conflicts of interest can occur when the agent is more concerned with his 
welfare than fulfilling his responsibility to the principal or owner (Jensen \& Meckling, 1976 in Puspitarini(2017). .

There is a relationship between agency theory and the preparation of financial statements. The government is not an agent that is the party entrusted to disclose all information needed by the user of Information (stakeholders) or principals. As users of financial report information, principals assess accountability and decide on social, political, and economic policies either directly or indirectly through their representatives. The relationship between the government and stakeholders as users of financial report information is the relationship of the agency

\section{Institutional Theory}

Institutional Theory explains how the structure of institutions affects processes within the organization (Grenwod \&Sudaby, 2006 in Kisworo and Shauki (2019) Through Institutional Theory, the researchers can understand individual and organizational behavior (Dacin, Godstein, \&Scot, 2002; Kisworo and Shauki (2019) . Institutional theory in public organizations explains actions and decision-making by leaders. The theoretical relationship with the preparation of financial statements is that the financial statements' preparation is in the same regulatory and legal environment. However, in terms of decision making, political pressure, the demands of professionalism, and other logical differences can affect different classifications, routines, scripts, schemes within each ministry

The difference in the logic of the financial report can be the dynamics of the initial changes in the organization. (J Shauki, E 2019). The primary application of accrual-based accounting is Institutional theory and New Public Management (NPM). In institutional theory, the government as the running agent issued functions and authority to implement the rules in accrual-based government accounting standards (Pramudiati, 2019).

\section{Stewardship Theory}

The principle of stewardship theory assumes that human beings can be trusted, act responsibly, have integrity, and be honest with others. In this theory, the main focus and objective of individuals in the organization are to put the organization's interests first. The manager acts as a steward and works following the owner's interests (Donaldson \&Davis, 1991 in Jefri 2018).

The connection of stewardship theory in this research is that the government acts as a steward who provides public services to the community. Transparency and accountability in preparing financial statements based on accrual Government Accounting Standards can meet users' financial statements and public satisfaction with state finances management.

\section{Human Resources Competency (HR)}

Competence is a fundamental thing that a person must have, including knowledge, skills, and skills related to work. These characteristics are inherent and directly affect the work so that it can produce the expected performance (McClelland in Rivai (2011:299). According to Spencer in Sudarmanto 2014:46, competence relates to established criteria for performance excellence in work and situation.

Indicators of human resource competency (employees) according to the Decree of the Head of the State Personnel Agency (BKN) No.46A year 2003, indicators of human resource competency (employees) include knowledge, skills, behavior/attitude. A person is generally gaining knowledge from education and 
experience implementing duties and responsibilities using skills in expertise and knowledge. Behavior/attitude is a response to accountability for all risks of the task given. Education is relevant to the indicators of knowledge in human resources. Skill indicators are mental and cognitive competencies, including analytical thinking, i.e., processing knowledge or data, determining causes and influences, and conceptual thinking (Spencer in Sudarmanto 2014:53). Behavioral Indicators in the preparation of financial statements are integrity, competence, and confidentiality.

\section{Leadership Commitment}

According to the 2014 Pandey, the measure of a leader's commitment, in this case, is delegation of authority to subordinates. The leader is committed to entrusting duties and responsibilities to the company. Instead, subordinates need to commit to improving self-competence. The responsibility for the retirement of financial statements of ministries and institutions depends on many parties. Top leaders of ministries and institutions work with their subordinates to produce financial reports. The cooperation of the top leader is to direct, influence, encourage his subordinates in carrying out the preparation of accrual-based government financial statements. Kouzes and Posner (2012) identified five leadership behaviors: Modeling the way, inspiring a shared vision, challenging a process, enabling others to act, and encouraging the heart.

\section{Information Technology Support}

According to Wiliam and Sawyer in Haryanto 2012, information technology helps people change, store, and communicate information. Today's information technology system to help establish the Accrual-Based Government Accounting System is SAIBA (Accrual-Based Agency Accounting System). Implementation of the integrated financial application system in line with the application of information technology system

The Minister of Finance issued regulation No. 213/PMK.05/2013 concerning Accounting and Financial Reporting System of the Central Government, to produce accountable financial statements, which is necessary for reconciliation to ensure the accuracy and accuracy of accounting data recording through electronic reconciliation (e-rekon). Reconciliation includes matching financial transaction data between the General Accounting System (SAU) and the Agency Accounting System (SAI). The Central Government Financial Report (LKPP) results from a consolidation of the Financial Statements of all Ministries and institutions as a picture of the overall finance management of the nation.

Several studies have developed a user-receiving computer technology model: the Technology acceptance model (TAM). Useful elements include (a)work more quickly, (b) improve job performance, (c) increase productivity, (d) enhance effectiveness, (e) be useful, and (f) make the job easier. Elements of convenience include (a) easy to learn, (b) controllable, (c) clear and understandable, (d) flexible, (e) easy to become skillfully, and (f) easy to use (Davis, 1986).

\section{InternalaControlaSystem Over FinancialaReporting}

Internal Control over Financial Reporting ensures that the resulting financial statements are reliable reports and prepared following government accounting standards. Regulation of the Minister of Finance of the Republic of Indonesia No.17/PMK.09/2019 governs the implementation of Internal Control over Financial Reporting. All accounting entities and financial reporting entities that compile 
central government financial statements must implement and design internal control over financial reporting at the entity and process or transaction levels.

Internal Control of the entity Level is a reasonable belief in the purpose of financial reporting that has a broad impact on the organization covering the entire process, transactions, accounts, or assertion in financial statements. Based on Regulation of the Minister of Finance No. 17/PMK.09/2019 internal control at the entity level may refer to applying internal control components and principles according to the Committee of Sponsoring Organizations of the Treadway Commission (COSO) Internal Control-Integrated Framework. COSO 2013 components consist of 5 components and 17 principles.

\section{Implementation of Accrual-Based Government AccountingaSystem}

Accrual-based financial statements provide information, cash receipts, payments, and future cash payment obligations and cash received in subsequent reporting periods. The benefits of accrual-based accounting implementation (Thompson in Widjajarso, 2011) is the government's financial position that is fully illustrated, showing information on government financing activities and providing information on government obligations.

The components of the financial statements under PP No. 71 Tahun 2010 at the Ministry and Institutions are the Budget Realization Report (LRA) balance sheet, Operational Report (LO), Equity Change Report (LPE), and Notes on the Financial Statements.

The accrual-based accounting concept is Revenue and Expense Recognition. Revenue recognition consists of income that still has to be received and prepaid income. Recognition of the expense consists of spending that still has to be prepaid expenses.

Accrued Income and expense adjustment is to update accrual-based accounting data. The reports presented meet the concept of periodicity and meet matching cost against revenue, although in government is not very highlighted. Presentation of income adjusted to the value of accrual income and expenses. An adjustment memo at the end of each period or year-end is a document that supports adjustment journal resources in the SAIBA application. Although several types of adjustments are made every semester following Regulation of the Minister of Finance No. 225/PMK.05/2016 concerning the Implementation of Accrual-Based Government Accounting Standards in the Central Government.

\section{Quality of Financial Statements}

Qualitative characteristics are normative measures in accounting information to meet the quality required in government financial statements relevant, reliable, comparable, and understandable. Relevant means that financial statements contain information that can evaluate past events and predict the future, thus helping stakeholders decide. Relevant information must have the benefit of feedback, have predictive benefits, be on time, complete.

Reliable is a financial statement free from misleading and material errors, presented honestly and verifiably. Reliable Information is Honest, Verifiable, Neutrality Presentation.

Comparable qualitative characteristics mean that financial statements made can be compared internally and externally between years. The accounting systems, guidelines, and policies used must be the same to compare the financial information. 
Understandable means that users of the financial report understand the content and the information and are assumed to know and desire to learn information about their entities and operating environment.

\section{Human Resources Competency affects The Implementation of Accrual- Based Accounting System}

The complexity of accrual-based accounting systems can lead to the rejection of implementation in applying accrual-based accounting. Human resource competencies significantly influenced the Implementation or Implementation of accrual-based accounting systems by Budiman, Slamet (2016),, Najati et al. (2016) , Sari(2017), Eriotis et al.(2011) research.

Therefore, the placement of Human Resources following the educational background, understanding the description of workers, and adapting to changes related to accrual-based accounting policy regulations are necessary to realize an accrual-based Government Accounting System. Although information technology has made it easier to prepare financial statements, input process errors may occur if not done correctly. Human resources still have an essential role in the successful implementation of the accrual-based Government Accounting System.

\section{HumanaResources Competency and Accrual-Based Accounting System Implementation}

Employees with appropriate educational backgrounds can understand job descriptions and adapt to changes related to accrual-based accounting policy regulations. Human resource competency has a vital role in the successful implementation of accrual-based Government Accounting Standards. The research results of Budiman, Najati et al. (2016) , Sari, Rissa Paramita (2017,)Eriotis et al. (2011) showed that human resource competencies significantly influenced the Implementation or Implementation of accrual-based accounting systems.

\section{Leadership's Commitment and Accrual-Based Accounting SystemaImplementation}

The leadership's commitment is the leader's involvement in disseminating accrual-based accounting system policies in writing to all employees, allocating sufficient resources, and being competent in their fields to ensure continuity. Thus, employees will be encouraged to implement the program with due regard to the prevailing regulations.

\section{Information Technology Support and Accrual-BasedaAccountinga Systema Implementationa}

The Accrual-based accounting constraints are the complexity of accounting recording systems: assessment, recognition, and reporting. The complexity of the accounting recording system requires information technology in its application. Therefore, the accounting system runs smoothly with the support of information technology. Puspitasari's research, Evita et al. (2016) showed that adjusting the development of accounting information system applications based on user needs can successfully implement accrual-based accounting systems. 


\section{InternalaControl overaFinancial Reportingaand Accrual-Based Accounting System Implementation}

Internal control over financial reporting provides adequate assurance that financial statements are reliably prepared and follow applicable rules. Accrual quality in financial operations and financial reporting can be attributed to weak internal controls Lashgari et al. (2015).

Human Resource Competency, Leadership's Commitment, Information Information Technology Support, Internal Control, and Accrual-Based Accounting System Implementation

Human Resources Competency, leadership commitment, and information technology support are needed to successfully implement the accrual-based Government Accounting System in the government environment. Nevertheless, there also needs to be an adequate internal control system to implement an accrualbased accounting system.

\section{Human Resources Competency and Quality of Financial Statements of Ministries and Institutions}

Financial Statements on an accrual basis have various valuations, recognitions, and reporting on assets, liabilities, and equity. So that Suppose the competence of human resources is not supported. In that case, it will affect the quality of financial statements. In financial statements management, good human resources competency is also required to produce good quality financial statements. As well as meeting the criteria of good financial report quality

\section{Leadership's Commitment and Quality of Financial Statements of ministries and institutions}

The complexity of the financial report recording system on an accrual accounting basis requires commitment support from the leadership for its implementation. The leadership's commitment can be seen from the involvement of leaders in implementing an accrual-based accounting system in writing that informs all employees, allocates sufficient resources, and is competent in their fields to ensure the organization's continuity. Thus, employees will be encouraged to implement the program with due regard to the prevailing regulations. The research results of Lubis and Saripudin. (2017) , Yusnita (2017) ,)Fitriani (2017), showed that Leadership Commitment significantly influenced the financial statements qualities.

\section{Information Technology Support and Quality of Financial Statements of ministries and institutions}

Accrual-based accounting constraints are the complexity of accounting recording systems, namely the choice of assessment, recognition, and reporting. The complexity of the accounting recording system requires information technology in its application. Therefore, the accounting system runs smoothly with the support of information technology. Therefore, to produce reliable financial reports, information technology plays an important role. 


\section{InternalaControl over FinancialaReporting and Quality of Financial Statements of ministries and institutions}

Internal Control over Financial Reporting is an internal control implemented by management to ensure financial statements are prepared based on applicable regulations. Financial transactions are conducted carefully and fairly with generally accepted accounting principles; Management prevents and identifies abuses of organizational asset management without authorization that could have a material impact on financial statements. Implementing adequate internal controls will provide adequate confidence in the quality or reliability of financial statements and increase stakeholder trust.

Human Resources Competency, Leadership's Commitment, Information Technology Support, Internal Control over Financial Reporting Human Resources and Quality of Financial Statements of ministries and institutions

Interaction between people and systems and system implementation are essential factors that affect the quality of information. Adequate human resources competencies in terms of quantity and quality will increase the value of information in government financial reporting. The leadership's commitment is the leader's involvement in disseminating accrual-based accounting system policies in writing to all employees, allocating sufficient resources, and being competent in their fields to ensure its continuity. Information Technology Supports accurate financial statements. The system is designed to maintain (preventive), detect (detective), and provide corrective mechanisms (corrective) to potential/possible errors (errors, omissions, errors) and abuse (fraud, fraud) that can affect the quality of financial statements of the Ministry and Institutions.

Implementation of Accrual-Based Government Accounting System and Quality of Financial Statements of Ministries and Institutions

The Principles of New Public Management (NPM) prioritize transparency and accountability of financial management, so accrual-based accounting is an international best practice in modern financial management. The accrual concept consists of two pillars; there are revenue recognition and cost/expense recognition. Accrual-based accounting financial statements provide more comprehensive information as the entire flow of resources that recorded. So that the better the implementation of accrual-based accounting, the more improved the quality of financial statements.

Human Resources Competency, Leadership Commitment, Information Technology Support, and Internal Control over Financial Reporting, Implementation of Accrual-Based Accounting System and Quality of Financial Statements of ministries and institutions

The complexity of accrual-based accounting can be an implementation constraint to the successful accrual-based accounting standards implementation. Therefore, it takes the competence of human resources and the commitment of leaders to unite determination and willingness to work to achieve the specified goals. In addition, Accounting System facilitates the implementation of accrualbased accounting in the government environment. The complexity of accrual-based accounting increases the risk of imbalance of all government rights and obligations that deserve to be recognized therefore require adequate internal control. The implementation of accrual-based accounting has implications for the quality of 
financial statements. The information produced is more comprehensive and follows the actual conditions on an accrual basis, improving the quality of financial statements useful in decision making. The better the implementation of accrualbased accounting, the better the quality of financial statements.

\section{Research Design and Hypotheses}

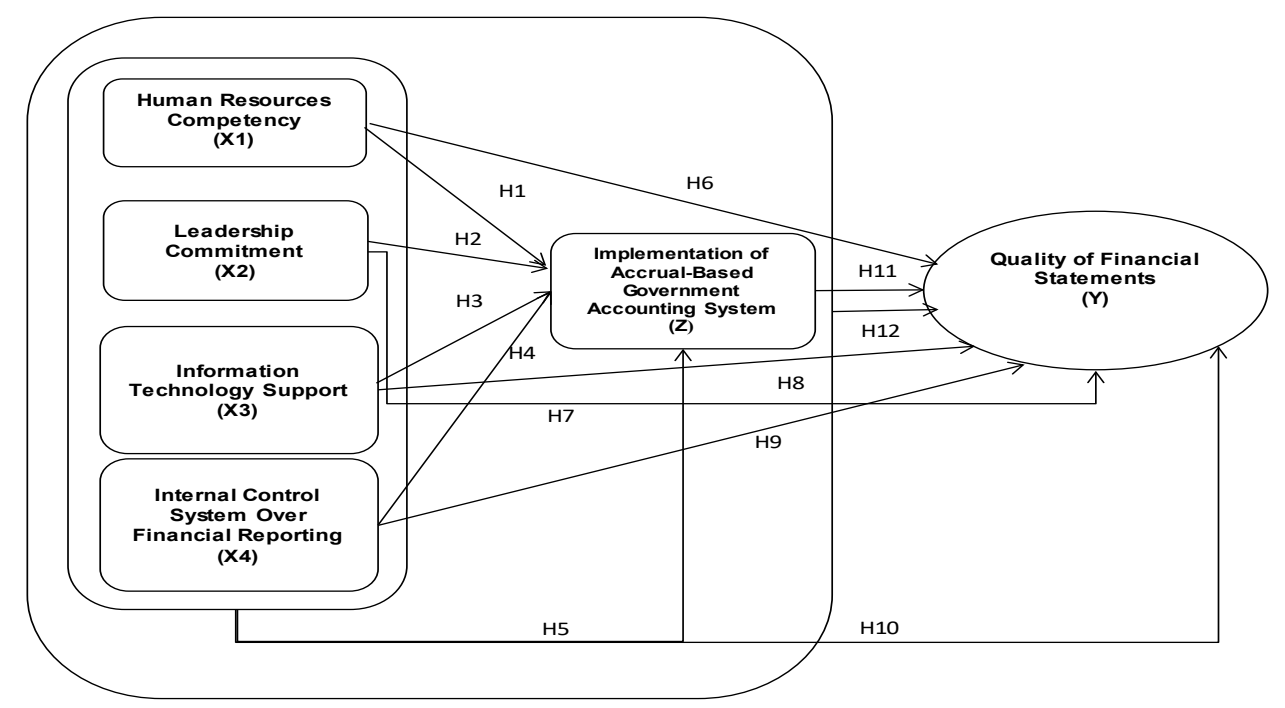

Figure 1 Research Design

H1: Human Resource Competency has a positive and significant effect on the Implementation of Accrual-Based Government Accounting System

H2: Leadership. Commitment. has a positive and significant. Effect. On the. Implementation of Accrual-Based.Government.Accounting.System

H3: Information Technology Support positively and significantly influences Information on The Implementation of Accrual-Based Government Accounting System

H4: Internal Control over Financial Reporting has a positive and significant effect on the Implementation of Accrual-Based Government Accounting System

H5: Human Resource Competency, Leadership Commitment, Information Information Technology Support, Internal Control together have a positive and significant effect on the Implementation of Accrual-Based Government Accounting System

H6: Human Resources Competency positively affects the Quality of Financial Statements of Ministries and Institutions

H7: The Leadership's Commitment has a positive and significant effect on the Quality of Financial Statements of ministries and institutions

H8: Information Technology Support has a positive and significant effect on the Quality of Financial Statements of Ministries and Institutions

H9: Internal Control over Financial Reporting has a positive and significant effect on the Quality of Financial Statements of ministries and institutions

H10: HR Competency, Leadership Commitment, Information Technology Support, Internal Control over Financial Reporting together have a positive and significant impact on the Quality of Financial Statements of ministries and institutions 
H11: Implementation of Accrual-Based Government Accounting System has a positive and significant effect on the Quality of Financial Statements of Ministries and Institutions

H12: HR Competency, Leadership Commitment, Information Technology Support, and Internal Control over Financial Reporting, Implementation of AccrualBased Accounting System has a positive and significant effect on the Quality of Financial Statements of Ministries and Institutions.

\section{RESEARCH METHODOLOGY}

\section{Population, Sample, and Respondents}

Population in Ministries and Institutions with The Results of Examination of Financial Statements WTP (Fair Without Exception) since 2015 until 2020. The methods and analysis in this study used Structural Equation Modelling (SEM). The criteria of ministries and institutions used in sampling are the Ministry of Institutions that obtained WTP financial statements from 2015 to 2020.

The respondent criteria are the compiler of the Financial Report at the Ministry/Institution level; The author of the financial report has work experience or occupies a position in the preparation of financial statements for at least two years of work and has a minimum educational background diploma. The sample of this study is the same as the population of 53 Ministries and Institutions that meet the Sampling Purposes. In this study, four financial report compilers as respondents who compiled financial statements at the ministry and institution level

\section{Operationalization of Variables}

\section{Human Resources Competency}

Human Resources Competency is a mastery of the tasks, skills, knowledge or expertise, abilities, or personal characteristics of individuals that directly affect the performance of the work. This variable is measured using an instrument (1) Knowledge with five indicators, namely recording, classification, summarizing, analyzing, reporting; (2) Skill with seven indicators, namely ability to create a journal for each adjustment transaction, post journals to general ledgers, compile and present Budget Realization Report, compile and present Operational Reports, compile and present balance sheets, compile and present Equity Change Reports, compile and present Notes on Financial Statements; (3) attitude with four indicators, namely integrity in maintaining the level of competence, Integrity of compliance with organizational rules, Integrity of the work can provide for integrity in confidentiality

\section{Leadership Commitment}

This variable is measured using an instrument by Kouzes dan Posner. According to Kouzes and Posner, leadership is the art of mobilizing others to fight to share aspirations. Variable Leadership commitment is defined in five exemplary behavior practices that are (1) Model The Way with three indicators, namely Examples in passion and hard work get the job done; Examples in work disciplines; Correct attitudes if you make mistakes; (2) Inspire a Shared Vision with three indicators, namely Involve employees in the vision of the organization; Explain what to achieve; Giving briefings in work; (3) Challenge, The Process with three indicators, namely The use of new ideas in problem-solving work; Ensuring every employee has goals and planning; Willing to take risks; (4), Enable Other To Act with three indicators, namely Creating an atmosphere of mutual respect and trust; 
Involve employees in decision making; Giving freedom of creativity in work; (5) Encourage The Heart with three indicators, namely Encouraging employees; Give praise; Celebrating success work program

\section{Information Technology Support}

Davis put forward the variable measured using the Model Technology acceptance model (TAM) in 1986. TAM has significant relevance to the computer (1) perceived usefulness with six indicators, namely, work more quickly, improve job performance, increase productivity, enhance effectiveness, Useful, Makes the job easier and s (2) perceived ease of use with six indicators, namely easy to learn, controllable, clear and understandable, flexible, easy to become skillful, easy to use.

\section{Internal Control System Over Financial Reporting}

This variable is measured using COSO (Committee of Sponsoring Organizations of the Treadway Commission) based on Regulation of the Minister of Finance of the Republic of Indonesia Number 17/PMK.09/2019 concerning Guidelines for Implementation, Assessment, and Review of Internal Control over Central Government Financial Reporting. The dimensions of the Internal Control System for Financial Reporting are (1) Environmental control with 5 indicators, namely Values of integrity and ethics; Independence of the Board of Trustees or the Audit Committee; Division of authority and responsibility; Commitment to competence; Policy practices and human resources; (2) Risk Assessment with 4 indicators, namely Setting the purpose of identification and risk assessment; Risk identification; Risk analysis and evaluation; Risk Assessment; (3) Control Activities, with 3 indicators, namely Mitigation of Process/Transaction Level Risk on Account or group of accounts; PUTIK Control (General Control of Information and Communication Technology); Policies and procedures; (4) Information and Communication with 3 indicators, namely Reliable and relevant Information; Internal communication of objective information and Internal control responsibility; External communication on internal control; (5) Monitoring with 2 indicators, namely Continuous monitoring; Perform a separate evaluation

\section{Implementation of Accrual-Based Government Accounting System}

This variable is measured using appendix I PP No. 71 of 2010 concerning Government Accounting Standards and PMK No. 225/PMK.05/2016 concerning accrual-based SAP Implementation. The variable is measured using an instrument

1) Recording Process with four indicators; namely Revenue recognition of Operational Reports; Revenue Recognition of Statement of Budget Realization; Cost Recognition; Expenditure Recognition.

2) Adjustment of Post/Accounts with 17 indicators based on Regulation of the Minister of Finance No. 225/PMK.05/2016 concerning the Implementation of Accrual-Based Government Accounting Standards; (3) Asset and Liability Management with four indicators, namely Inventory Management, Fixed Asset Valuation, Depreciation of Fixed Assets, Liability Assessment; (4) Presentation of Financial Reporting with four indicators, namely statement of Budget Realization Report, Balance Sheet Presentation; Presentation of Operational Reports; Presentation of Equity Change Report. 


\section{Quality of Financial Statements of Ministries and Institutions}

This variable is measured using by quality characteristics of financial reporting based on PP No. 71 of 2010 that are (1) Relevance with four indicators, namely feedback value, predictive value, On time, Complete; (2) Faithfull Representation with three indicators, namely Honest Presentation, Verifiability, Neutrality (3) Comparability means financial statements can be compared with the previous year or with the financial statements of other entities both internally and externally, (4) Understandability with two indicators, namely user understand the financial statement information easily; Terms used in conveying information can be accepted and understood by users.

\section{Data analysiss methodd}

Hypothesis testing using Structural Equation Modeling (SEM) data analysis techniques. This research uses the analysis technique method LISREL 8.8 (Linear Structural Relationship software) method of analysis techniques is as follows: (1) Normality test, this study used two tests, namely univariate normality test and multivariate normality; (2) The assumption of multicolerity is used to know there is no colinearity or perfect relationship between variables; (3) Measurement Model or Confirmatory Factor Analysis (CFA) includes Convergent Validity Test, Discriminant Validity, Reliability Test; (4) Model Overall Match Test with Goodness of Fit Test; (5) Structural Model match test is used to link relationships between previously hypothesized variables; (6) Hypothesis Test through Partial Hypothesis Test, Simultaneous Hypothesis Test, and; (7) Coefficient of Determination.

\section{RESULT}

\section{Characteristics of Respondents}

Respondents in this study as much as $53.7 \%$ by bachelor's education then respondents with master's education as much as $46.3 \%$. Based on experience, most of the respondents have experienced for $>5$ years which is $53.7 \%$ then the remaining $46.3 \%$ of respondents experienced for $2-5$ years.

\section{Perception of Respondents}

Researchers used maximum and minimum values to find out respondents' responses to the variable to be studied. The scale in this study used a Likert scale of $1-5$, where scale 1 showed strongly disagreed, and a scale of 5 showed strongly agreed

\begin{tabular}{|ccc|}
\hline Table 1 Respondent Perception of HR Competency & Variables \\
\hline Indicator & Average & St.Dev \\
\hline Knowledge & 4,037 & 0,844 \\
\hline Skill & 4,074 & 0,780 \\
\hline Attitude & 4,074 & 0,780 \\
\hline Variable Average & $\mathbf{4 , 0 6 1}$ & $\mathbf{0 , 8 0 1}$ \\
\hline
\end{tabular}

Respondent responses to HR competency variables are measured using three indicators. The total average value of hr competency variables was 4,061, indicating that respondents tended to answer agreed. The highest average is in the Skill and Attitude indicators, with an average of 4,074. In contrast, the lowest average is on the Knowledge indicator, with an average value of 4,037. 


\begin{tabular}{|ccc|}
\hline \multicolumn{3}{c}{ Table 2 Respondents Perception of The Variable of Leadership Commitment } \\
\hline Indicator & Average & St.Dev \\
\hline Model The Wayy & 4,144 & 0,739 \\
\hline Inspire a Shared Vision & 4,119 & 0,770 \\
\hline Challenge The Process & 4,251 & 0,681 \\
\hline Enable Other to Act & 4,153 & 0,762 \\
\hline Encourage The Heart & 4,247 & 0,652 \\
\hline Variable Average & $\mathbf{4 , 1 8 3}$ & $\mathbf{0 , 7 2 1}$ \\
\hline
\end{tabular}

Respondent responses to the Leadership Commitment variable are measured using five indicators. The total average value of the Leadership Commitment variable was 4,183 , indicating that respondents tended to answer agreed. The highest average is on the Indicator Providing solutions in completing the work (Challenge the Process), with an average of 4,251. While the lowest average is in the indicator Inspire a Shared Vision, with an average value of 4,119.

Table 3 Respondent Perception of Information Technology Support Variables

\begin{tabular}{ccc}
\hline Indicator & Average & St.Dev \\
\hline Perceivedd usefulnesss & 4,116 & 0,725 \\
\hline Perceivedd ease of usee & 4,126 & 0,738 \\
Variable Average & $\mathbf{4 , 1 8 3}$ & $\mathbf{0 , 7 2 1}$
\end{tabular}

Respondent responses to the Information Technology Support variable are measured using two indicators. The total average value of the Information Technology Support variable was 4,121, indicating that respondents were more likely to agree. The highest average is on the Ease indicator, with an average of 4,126 . In contrast, the lowest average is on the Benefit indicator with an average value of 4,116 .

\begin{tabular}{|ccc|}
\hline Table 4 Respondent Perception of Variables Internal Control over Financial Reporting \\
\hline Indicator & Average & St.Dev \\
\hline Environmental control & 4,091 & 0,626 \\
Risk Assessment & 3,986 & 0,808 \\
Control Activities & 4,084 & 0,831 \\
\hline Information and Communication & 4,025 & 0,840 \\
Monitoring & 4,024 & 0,756 \\
Variable Average & $\mathbf{4 , 1 8 3}$ & $\mathbf{0 , 7 2 1}$ \\
\hline
\end{tabular}

Respondent responses to internal control variables on Financial Reporting were measured using five indicators. The total average value of internal control variables for Financial Reporting was 4,042, indicating that respondents agreed. The highest average is on the Control Environment indicator, with an average of 4,091. In contrast, the lowest average is on the risk assessment indicator, with an average value of 3,986 . 


\begin{tabular}{ccc}
$\begin{array}{l}\text { Table } \mathbf{5} \text { Respondents Perception of Variables in } \\
\text { Government Accounting Systemm }\end{array}$ & The & Implementation of Accrual-Based \\
\hline Indicator & Average & St.Dev \\
\hline Recording Process & 3,953 & 0,825 \\
\hline Adjustment of Post /Account & 4,089 & 0,761 \\
Asset and Liability & 3,905 & 0,843 \\
\hline Presentation of Financial Reporting & 3,853 & 0,948 \\
Variable Average & $\mathbf{4 , 1 8 3}$ & $\mathbf{0 , 7 2 1}$ \\
\hline
\end{tabular}

Respondent responses to the variables of Accrual-Based Government Accounting System Implementation are measured using four indicators. The total average value of the Accrual-Based Government Accounting System Implementation variable was 3,950, indicating that respondents tended to answer agreed. The highest average is on the indicator Adjustment, with an average of 4,089. In contrast, the lowest average is on the Financial Reporting Presentation indicator, with an average value of 3,853.

\begin{tabular}{|c|c|c|}
\hline \multicolumn{3}{|c|}{ Table 6 Respondent Perception of Financial Report Quality Variables } \\
\hline Indicator & Average & St.Dev \\
\hline Relevance & 4,009 & 0,811 \\
\hline Faithfull Representation & 4,130 & 0,665 \\
\hline Comparability & 4,074 & 0,923 \\
\hline Understandability & 4,047 & 0,944 \\
\hline Variable Average & 4,183 & 0,721 \\
\hline
\end{tabular}

Respondent responses to the Financial Report Quality variable are measured using four indicators. The total average value of the Financial Report Quality variable was 4,065, indicating that respondents were more likely to agree. The highest average is on the Faithfull Representation indicator, with an average of 4,130 . In contrast, the lowest average is on the Relevant indicator (Relevance), with an average value of 4,009 .

\section{Normality Test}

Normality Tests are observing the p-value of skewness and kurtosis. If the pvalue value $>$ significant alpha $5 \%$ or 0.05 , the data is normally distributed assumptions of normality are fulfill). Conversely, if the p-value $<$ significant alpha $5 \%$ or 0.05 , it can be categorized as abnormal data distribution

\begin{tabular}{|c|c|c|c|c|}
\hline \multicolumn{5}{|c|}{ Table 7 Univariate Normality } \\
\hline \multirow[t]{2}{*}{ No } & \multirow[t]{2}{*}{ Variable } & \multicolumn{2}{|c|}{ Skewness and Kurtosis } & \multirow[t]{2}{*}{ Information } \\
\hline & & Chi-Square & P-Value & \\
\hline 1 & $\mathrm{X} 1.1$ & 10,173 & 0,006 & Not Normal \\
\hline 2 & $\mathrm{X} 1.2$ & 8,692 & 0,013 & Not Normal \\
\hline 3 & $\mathrm{X} 1.3$ & 26,823 & 0,000 & Not Normal \\
\hline 4 & $\mathrm{X} 2.1$ & 18,747 & 0,000 & Not Normal \\
\hline 5 & $\mathrm{X} 2.2$ & 17,392 & 0,000 & Not Normal \\
\hline 6 & $\mathrm{X} 2.3$ & 23,764 & 0,000 & Not Normal \\
\hline 7 & $\mathrm{X} 2.4$ & 22,053 & 0,000 & Not Normal \\
\hline 8 & $\mathrm{X} 2.5$ & 12,521 & 0,002 & Not Normal \\
\hline 9 & X3.1 & 47,602 & 0,000 & Not Normal \\
\hline
\end{tabular}


Amrizal, Hamilah, And Afiifun Marjaana

\begin{tabular}{|lllll|}
\hline 10 & X3.2 & 63,280 & 0,000 & Not Normal \\
\hline 11 & X 4.1 & 37,349 & 0,000 & Not Normal \\
\hline 12 & X 4.2 & 47,907 & 0,000 & Not Normal \\
\hline 13 & X 4.3 & 25,347 & 0,000 & Not Normal \\
\hline 14 & X 4.4 & 50,418 & 0,000 & Not Normal \\
\hline 15 & X .5 & 19,883 & 0,000 & Not Normal \\
\hline 16 & Z.1 & 20,972 & 0,000 & Not Normal \\
\hline 17 & Z.2 & 16,082 & 0,000 & Not Normal \\
\hline 18 & Z.3 & 7,051 & 0,029 & Not Normal \\
\hline 19 & Z.4 & 14,520 & 0,001 & Not Normal \\
\hline 20 & Y.1 & 16,472 & 0,000 & Not Normal \\
\hline 21 & Y.2 & 11,386 & 0,003 & Not Normal \\
\hline 22 & Y.3 & 27,892 & 0,000 & Not Normal \\
\hline 23 & Y.4 & 22,780 & 0,000 & Not Normal \\
\hline
\end{tabular}

The results showed that all indicators produced p-value $<$ significant alpha $5 \%$ or 0.05 , all data indicators used in this study Univariate are not normally distributed. The data in this study did not generally distribute because the respondents' responses to all the questions did not spread evenly and mainly to the right. Therefore, to decide whether the overall data is declared normal or not, it can use the multivariate normality test to reference its normality.

\begin{tabular}{|cccccccc|}
\hline \multicolumn{3}{|c}{ Table 8 Univariate Normality } & & & \\
\hline \multicolumn{3}{c}{ Skewnes } & & Kurtosi & \multicolumn{3}{c|}{ Skewness and Kurtosis } \\
\hline Value & Z-Score & P-Value & Value & Z-Score & P-Value & Value & P-Value \\
77,267 & 2,130 & 0,033 & 572,406 & 0,772 & 0,470 & 5,057 & 0,080 \\
\hline
\end{tabular}

Multivariate normality testing results in p-value > significant alpha value of $5 \%$ or 0.05 . Multivariate generally distributed so that the assumption of normality is fulfilling.

\section{Multicollinearity Assumption}

The assumption of multicolerity is to know there is no colinearity or perfect relationship between variables. Test criteria if the correlation between variables is not worth $>0.80$, there is no relationship between variables.

\begin{tabular}{|c|c|c|c|c|c|}
\hline & $Y$ & Z & $\mathrm{X} 1$ & $\mathrm{X} 2$ & X3 \\
\hline Y & 1.00 & & & & \\
\hline Z & 0.69 & 1.00 & & & \\
\hline $\mathrm{X} 1$ & 0.68 & 0.62 & 1.00 & & \\
\hline X2 & 0.34 & 0.23 & 0.28 & 1.00 & \\
\hline X3 & 0.60 & 0.60 & 0.75 & 0.11 & 1.00 \\
\hline X4 & 0.36 & 0.35 & 0.20 & 0.20 & 0.13 \\
\hline
\end{tabular}

Figure 2 Multicole rity Test Correlation Matrix of ETA and KSI

Based on the results, there is no correlation value between variables that is more than 0.80 . It indicates no significant relationship between variables, so the assumption of Multicollinearity is fulfilled. 


\section{Measurement Model}

Measurement models are referred to as Confirmatory Factor Analysis (CFA). Convergent validity rating is seen from the loading factor value for each indicator. Construct validity testing is conducted using standardized loading estimate = standardized regression wights results from cConfirmatory fFactor Analysis/ CFA.

\section{Convergent Validity}

The value of the loading factor is significant, or the standardized loading estimate $=$ standardized regression weights $\geq 0.50$ (ideally 0.70 ). And in CFA, the percentage of the average value of variance Extracted (AVE) between items or indicators of a set of latent constructs is a convergent summary indicator Convergent Validity Test

\begin{tabular}{|c|c|c|c|c|}
\hline Variable & $\begin{array}{l}\text { Item } \\
\text { Code }\end{array}$ & $\begin{array}{l}\text { Stadardized Factor } \\
\text { Loading }\end{array}$ & $\begin{array}{l}\text { Cut } \\
\text { Off }\end{array}$ & AVE \\
\hline \multirow[t]{3}{*}{ Human Resources Competency (X1) } & X1.1 & 0,90 & $>0,50$ & 0,663 \\
\hline & $\mathrm{X} 1.2$ & 0,83 & $>0,50$ & \\
\hline & $\mathrm{X} 1.3$ & 0,70 & $>0,50$ & \\
\hline \multirow[t]{5}{*}{ Leadership Commitment (X2) } & $\mathrm{X} 2.1$ & 0,71 & $>0,50$ & 0,617 \\
\hline & $\mathrm{X} 2.2$ & 0,67 & $>0,50$ & \\
\hline & $\mathrm{X} 2.3$ & 0,91 & $>0,50$ & \\
\hline & X2.4 & 0,91 & $>0,50$ & \\
\hline & $\mathrm{X} 2.5$ & 0,69 & $>0,50$ & \\
\hline \multirow[t]{2}{*}{ Information Technology Support (X3) } & X3.1 & 0,85 & $>0,50$ & 0,650 \\
\hline & X3.2 & 0,76 & $>0,50$ & \\
\hline \multirow{5}{*}{$\begin{array}{c}\text { Internal Control System Over Financial } \\
\text { Reporting (X4) }\end{array}$} & $\mathrm{X} 4.1$ & 0,82 & $>0,50$ & 0,689 \\
\hline & $\mathrm{X} 4.2$ & 0,84 & $>0,50$ & \\
\hline & $\mathrm{X} 4.3$ & 0,82 & $>0,50$ & \\
\hline & $\mathrm{X} 4.4$ & 0,83 & $>0,50$ & \\
\hline & $\mathrm{X} 4.5$ & 0,84 & $>0,50$ & \\
\hline \multirow{4}{*}{$\begin{array}{l}\text { Implementation of Accrual-Based } \\
\text { Government Acconting Syste, (Z) }\end{array}$} & $\mathrm{Z} .1$ & 0,83 & $>0,50$ & 0,657 \\
\hline & $\mathrm{Z} .2$ & 0,83 & $>0,50$ & \\
\hline & Z.3 & 0,79 & $>0,50$ & \\
\hline & Z.4 & 0,79 & $>0,50$ & \\
\hline \multirow[t]{4}{*}{$\begin{array}{l}\text { Quality of Financial Statements of Ministries } \\
\text { and Institutions (Y) }\end{array}$} & Y.1 & 0,88 & $>0,50$ & 0,771 \\
\hline & Y.2 & 0,84 & $>0,50$ & \\
\hline & Y.3 & 0,89 & $>0,50$ & \\
\hline & Y.4 & 0,90 & $>0,50$ & \\
\hline
\end{tabular}

Based on the table above, that all indicators are declared valid. The standardized loading factor value obtained by each indicator is more significant than 0.5. Moreover, all variables produce an AVE value greater than 0.5.

\section{Discriminant Validity}

The discriminant validity test is to measure how far a construct is entirely different from other constructs. How to test it with Compare $\sqrt{\text { AVE }}$ with correlations 
between constructs. If $\sqrt{A V E}>$ correlation between constructs, it indicates a good convergent validity.

\begin{tabular}{|c|c|c|c|c|c|c|}
\hline \multicolumn{7}{|c|}{ Table 10 Discriminant Validity Test } \\
\hline & $\mathbf{Y}$ & 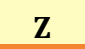 & & & X3 & X4 \\
\hline Y & 0,88 & 0,6 & 0,62 & 0,23 & 0 & 0,35 \\
\hline $\mathrm{Z}$ & 0,69 & 0,93 & 0,68 & 0,34 & 0,60 & 0,36 \\
\hline $\mathrm{X} 1$ & $0, \epsilon$ & & & & & \\
\hline $\mathrm{X} 2$ & 0,23 & 0,34 & 0,28 & 39 & 0,1 & 0,20 \\
\hline X3 & 0,60 & 0,60 & 0,75 & 0,11 & 0,79 & 0,13 \\
\hline $\mathrm{X} 4$ & 0,35 & 0,36 & 0,20 & 0,20 & 0.13 & 0,92 \\
\hline
\end{tabular}

The table shows that the $\sqrt{A V E}$ on each variable $>$ correlation between constructs on other variables has an excellent convergent validity

\section{Reliability Test}

Instruments with construct reliability show the instrument is reliable, which is indicated by the value of the reliability construct has met the acceptable limit. Thus, all indicators on all variables have been reliable.

\begin{tabular}{|c|c|c|c|c|c|}
\hline \multicolumn{6}{|l|}{ Table 11 Reliability Test } \\
\hline Variable & Indicatora & $\begin{array}{l}\text { Standardized } \\
\text { Factora } \\
\text { Loadinga }\end{array}$ & $\begin{array}{c}\text { SFL } \\
\text { Kuadrat } \\
\text { (Persepsi) }\end{array}$ & $\begin{array}{c}\text { Errora } \\
{[\varepsilon j]}\end{array}$ & $\begin{array}{l}\text { Construct } \\
\text { Reliability }\end{array}$ \\
\hline \multirow{3}{*}{$\begin{array}{l}\text { Human Resources } \\
\text { Competency (X1) a }\end{array}$} & $\mathrm{X} 1.1 \mathrm{a}$ & 0,9 & 0,810 & 0,190 & 0,854 \\
\hline & $\mathrm{X} 1.2 \mathrm{a}$ & 0,83 & 0,689 & 0,311 & \\
\hline & $\mathrm{X} 1.3 \mathrm{a}$ & 0,7 & 0,490 & 0,510 & \\
\hline Total & & 2,430 & 1,989 & 1,011 & \\
\hline \multirow{5}{*}{$\begin{array}{c}\text { Leadership } \\
\text { Commitment (X2) a }\end{array}$} & $\mathrm{X} 2.1 \mathrm{a}$ & 0,71 & 0,504 & 0,496 & 0,888 \\
\hline & $\mathrm{X} 2.2 \mathrm{a}$ & 0,67 & 0,449 & 0,551 & \\
\hline & $\mathrm{X} 2.3 \mathrm{a}$ & 0,91 & 0,828 & 0,172 & \\
\hline & $\mathrm{X} 2.4 \mathrm{a}$ & 0,91 & 0,828 & 0,172 & \\
\hline & $\mathrm{X} 2.5 \mathrm{a}$ & 0,69 & 0,476 & 0,524 & \\
\hline Total & & 3,890 & 3,085 & 1,915 & \\
\hline $\begin{array}{l}\text { Information Technology } \\
\text { Support }\end{array}$ & X3.1a & 0,85 & 0,723 & 0,278 & 0,787 \\
\hline$(\mathrm{X} 2) \mathrm{a}$ & $\mathrm{X} 3.2 \mathrm{a}$ & 0,76 & 0,578 & 0,422 & \\
\hline Total & & 1,610 & 1,300 & 0,700 & \\
\hline \multirow{5}{*}{$\begin{array}{c}\text { Internal Control System } \\
\text { Over Financial } \\
\text { Reporting (X4) a }\end{array}$} & $\mathrm{X} 4.1 \mathrm{a}$ & 0,82 & 0,672 & 0,328 & 0,917 \\
\hline & $\mathrm{X} 4.2 \mathrm{a}$ & 0,84 & 0,706 & 0,294 & \\
\hline & $\mathrm{X} 4.3 \mathrm{a}$ & 0,82 & 0,672 & 0,328 & \\
\hline & $\mathrm{X} 4.4 \mathrm{a}$ & 0,83 & 0,689 & 0,311 & \\
\hline & $\mathrm{X} 4.5 \mathrm{a}$ & 0,84 & 0,706 & 0,294 & \\
\hline Total & & 4,150 & 3,445 & 1,555 & \\
\hline $\begin{array}{c}\text { Implementation of } \\
\text { Accrual-Based } \\
\text { Government Accounting } \\
\text { System }\end{array}$ & Z.1a & 0,83 & 0,689 & 0,311 & 0,884 \\
\hline
\end{tabular}




$\begin{array}{cccccc}\text { (Z)a } & \text { Z.2a } & 0,83 & 0,689 & 0,311 & \\ & \text { Z.3a } & 0,79 & 0,624 & 0,376 & \\ \text { Total } & \text { Z.4a } & 0,79 & 0,624 & 0,376 & \\ \text { Quality of Financial } & \text { Y.1a } & \mathbf{3 , 2 4 0} & \mathbf{2 , 6 2 6} & \mathbf{1 , 3 7 4} & \\ \begin{array}{c}\text { Statements of } \\ \text { Ministries and }\end{array} & & 0,88 & 0,774 & 0,226 & 0,931 \\ \text { Institutions (Y)a } & & & & & \\ & \text { Y.2a } & 0,84 & 0,706 & 0,294 & \\ & \text { Y.3a } & 0,89 & 0,792 & 0,208 & \\ \text { Total } & \text { Y.4a } & 0,9 & 0,810 & 0,190 & \\ \text { Acceptable Limits } & & \mathbf{3 , 5 1 0} & \mathbf{3 , 0 8 2} & \mathbf{0 , 9 1 8} & \mathbf{0 , 7}\end{array}$

\section{The goodness of Fit Test}

measurement models and structural models of parameters are estimated together and must meet fit models and vital theories.

\begin{tabular}{|c|c|c|c|}
\hline \multicolumn{4}{|c|}{ Table 11 Goodness of Fit Testing Table } \\
\hline Criteria & Goodness of Fit Results & Cut-off Value & Model Evaluation \\
\hline GFI & 0,86 & $\geq 0,9$ & Marginal Fit \\
\hline AGFI & 0,82 & $\geq 0,9$ & Marginal Fit \\
\hline NFI & 0,95 & $\geq 0,9$ & Good Fit \\
\hline IFI & 0,98 & $\geq 0,9$ & Good Fit \\
\hline CFI & 0,98 & $\geq 0,9$ & Good Fit \\
\hline RFI & 0,94 & $\geq 0,9$ & Good Fit \\
\hline RMSEA & 0,058 & $<0,08$ & Good Fit \\
\hline TLI/NNFI & 0,98 & $\geq 0,9$ & Good Fit \\
\hline
\end{tabular}

the table shows that more than five goodness of fit criteria have met the cut-off value, meaning that the evaluation results show a good model. It explains that the model used in this study produced the expected rate of guessing. Thus, this model is good, and it is worth explaining the interrelationship between variables in the model.

\section{Structural Model}

The structural Model match is a test to link relationships between previously hypothesized variables.

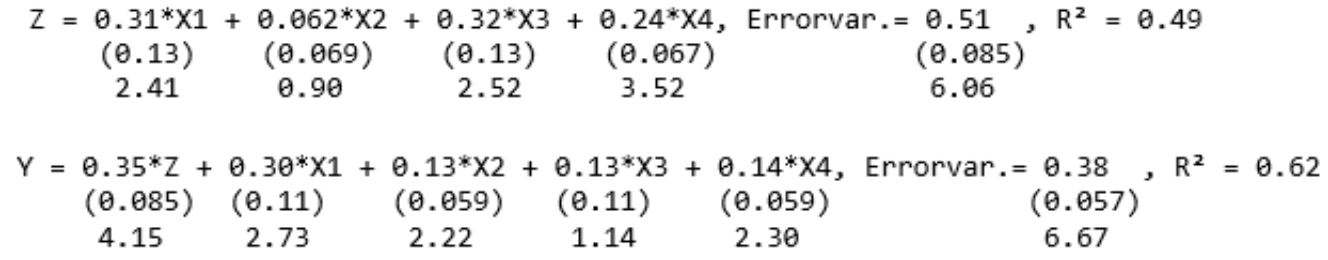

Figure 3 Struktural Equation 


\section{Hypothesis Test}

A hypothesis test is to know the signification of the results of Structural Equation Modelling. The test criteria state that if the value is |t-value| greater than 1.96 or the probability value $<$ level of significance (alpha $=5 \%$ or 0.05 ) expressed the influence of independent variables on dependent variables.

\begin{tabular}{cccccc}
\hline \multicolumn{7}{c}{ Table 12 Partial Hypothesis Test Table } & & & \\
\hline Hypothesis & Relationship & Estimate & T-Value & Cut Off & Information \\
\hline H1 & X1 à Z & 0,31 & 2,41 & $>1,96$ & Significant \\
\hline H2 & X2 à Z & 0,062 & 0,90 & $<1,96$ & Insignificant \\
H3 & X3 à Z & 0,32 & 2,52 & $>1,96$ & Significant \\
\hline H4 & X4 à Z & 0,24 & 3,52 & $>1,96$ & Significant \\
H6 & X1 à Y & 0,30 & 2,73 & $>1,96$ & Significant \\
\hline H7 & X2 à Y & 0,13 & 2,22 & $>1,96$ & Significant \\
\hline H8 & X3 à Y & 0,13 & 1,14 & $<1,96$ & Insignificant \\
\hline H9 & X4 à Y & 0,14 & 2,30 & $>1,96$ & Significant \\
\hline H11 & Z à Y & 0,30 & 4,15 & $>1,96$ & Significant \\
\hline
\end{tabular}

\begin{tabular}{|ccccccc|}
\hline \multicolumn{6}{c}{ Table 13 Simultaneous Hypothesis Test Table } \\
\hline Hypothesis & R Square & N & k & Fhitung & Ftabel & Information \\
H5 & 0,49 & 190 & 4 & 44,44 & 2,420 & Significant \\
H10 & 0,56 & 190 & 4 & 58,86 & 2,420 & Significant \\
H12 & 0,62 & 190 & 5 & 60,04 & 2,263 & Significant \\
\hline
\end{tabular}

\begin{tabular}{|ccccc|}
\hline \multicolumn{4}{|c|}{ Table 14 Indirect Influence Hypothesis Test Table } \\
\hline Relationship & Estimate & T-Value & Cut Off & Information \\
X1 à Z à Y & 0,11 & 2,12 & $>1,96$ & Significant \\
X2 à Z à Y & 0,02 & 0,88 & $<1,96$ & Insignificant \\
X3 à Z à Y & 0,11 & 2,18 & $>1,96$ & Significant \\
X4 à Z à Y & 0,08 & 2,73 & $>1,96$ & Significant \\
\hline
\end{tabular}

\section{Coefficient of Determination}

The Determination Coefficient is used to the magnitude of the contribution of independent variables to dependent variables.

\begin{tabular}{|cc|}
\hline Table 15 Coefficient of Determination & \\
\hline Dependent Variable & $\boldsymbol{R}^{\mathbf{2}}$ \\
\hline Implementation of Accrual-Based Government Accounting System (Z) & $\mathbf{0 , 4 9}$ \\
\hline Quality of Financial Statements of Ministries and Institutions (Y) & $\mathbf{0 , 6 2}$ \\
\hline
\end{tabular}

R-square in the implementation model of Accrual-based Government Accounting Standards (Z) indicates the influence of human resource competency variables, Leadership Commitment, Information Technology Support, and Internal Control to the Implementation of Accrual-Based Accounting Standards by $49.0 \%$. In comparison, the remaining $51.0 \%$ was the contribution of other variables not discussed in this study. Meanwhile, R-square on the quality model of the Ministry and Institution Financial Statements (Y) indicates the contribution of the influence 
of human resource competency variables, Leadership Commitment, Information Technology Support, Internal Control over Financial Reporting, and Implementation of Accrual-Based Accounting System to the Quality of Ministry and Institution Financial Statements (Y) by $62.0 \%$, while the remaining $38.0 \%$ is another variable contribution not discussed in this study.

\section{CONCLUSION AND DISCUSSION}

Human Resource Competency (X1) on Implementation of Accrual-Based Government Accounting Standardss (Z)

produces a $\mathrm{T}$ statistical value $2.41>\mathrm{T}$-table 1.96 with the estimated value indicated positive value, which is 0.31 . The positive value estimates indicate that the higher the Human Resources Competency, the more likely it is to improve the Implementation of Accrual-Based Government Accounting Standards. This is in line with the research results of Hasil penelitian sejalan dengan penelitian Pattiasina (2019); Najati et al. (2016),; Budiman, Slamet (2016),, Paramita Sari, Rissa (2017), Yogiswara, I Wayan Gede Farma Putra and Ariyanto (2015). ; Kusuma (2013); Eriotis et al.(2011); Evita et al. (2016); Herwiyanti et al.(2017); Ardiansyah (2013); Nufus (2014).; Pamungkas (2012).; Puspitarini (2017). ; Sukadana and Mimba (2015); Kencana, I Gusti Bagus Surya (2015); Waspodo et al. (2017) showed that Human Resource Competency has a significant influence on the implementation or implementation of accrual-based accounting systems. Competency demonstrates skills or knowledge characterized by professionalism in a particular field due to experience, educational background, and accounting training.

\section{Leadership Commitment (X2) on IImplementation of aAccrual-Based Government Accounting Standardss (Z)}

Produces a T statistical value $0.90<\mathrm{T}$-table 1.96 with the estimated value indicated as positive, which is 0.062 . The t-value is smaller than T-table 1.96. The results are not in line with budiman, Slamet (2016),; Paramita Sari, Rissa (2017), Yogiswara, I Wayan Gede Farma Putra and Ariyanto (2015). ; Evita et al. (2016); Puspitarini (2017). ; Waspodo et al. (2017) research. The study results are different from previous research because of differences in research respondents and leadership at the level of ministries and institutions that are mandatory, where is still needed the competence of accrual accounting understanding for communication between leaders in conveying transaction information is accrual.

\section{Information Technology Support (X3) on Implementation of Accrual- Based Government Accounting Standards (Z)}

Produces a T statistical value $2.52>$ T-table 1.96 with a positive estimate value of 0.32 . The positive value of the estimate indicates that the higher the Information Technology Support, the more likely it is to improve the Implementation of AccrualBased Government Accounting Standards. Research results in line with Rasyidah Hasyim (2017); Agung, Tut Madiguna and Gayatri (2018); Yusnita (2017) ; Aryani (2013); Winidyaningrum (2010).. The quality of IT and the successful adoption of Accrual Accounting reforms have a positive and significant relationship.

Internall Control over Financial Reporting (X4) on Implementationn of Accrual-Based Government Accounting Standardss (Z)

Produces a T statistical value $3.52>$ T-table 1.96 with the estimated value indicated as positive, which is 0.32 . The positive value of estimates indicates that 
the higher internal control over financial reporting is likely to improve accrualbased government accounting standards. Research results are in line with Pattiasina, Victor dan Muhamad Yamin Noah (2019), Lashgari et al. (2015) Internal control weaknesses can be attributed to accrual quality to impact financial operations and reporting within the company

HR Competency (X1), Leadership Commitment (X2), Technology Support (X3), Internal Control over Kuangan Reporting together (X4) on Implementation of Accrual-Based Government Accounting Standards (Z)

Produces F statistical value 44,44 > T-table 2.42 with the estimated value indicated as positive. The positive value of estimates shows that the higher HR competencies, leadership commitments, information technology support, internal control over financial reporting tend to improve accrual-based government accounting standards. Research results are in line with Budiman, Slamet (2016); Eriotis et al.(2011); Evita Puspitasari, Sri Mulyani, Devianti Yunita (2016); Herwiyanti, Elianda et al. (2017); Kencana, I Gusti Bagus Surya (2015); Kusuma (2013); Najati, Ida et al. (2016)Najati, Ida, Endar Animah (2016); Nufus (2014); Pamungkas (2012):; Paramita Sari, Rissa (2017); Pattiasina (2019); Puspitarini, Intan et al. (2017); Rasyidah, Nadir dan Hasyim (2017)Rasyidah, Nadir dan Hasyim. (2017); Sukadana and Mimba (2015); Waspodo et al. (2017) Yogiswara, I Wayan Gede Farma Putra and Ariyanto (2015).

Human Resources Competency (X1) on Quality of Financial Statements of Ministries and Institutions (Y) produces a T statistical value 2,73 > T-table 1.96 with a positive estimate value of 0.3 . The positive value of the estimate indicates that the higher the Human Resources Competency, the more likely it is to improve the Quality of Financial Statements of ministries and institutions. Research results in line with I Wayan and I Gusti Ngurah Agung Suaryana (2017); Agung, Tut Madiguna and Gayatri (2018); Lubis and Saripudin(2017) ; Yusnita (2017) ; Mardiana, Rizki and Heru Fahlevi (2017); Aryani (2013); Kristyono et al. (2013); Winidyaningrum (2010). research. Human resources competency has a positive impact on the quality of financial statements because it has an essential role in achieving organizational goals.

Leadership Commitment (X2) on Quality of Financial Statements of Ministries and Institutions (Y) produces a T statistical value 2,73 > T-table 1.96 with a positive estimate value of 0.13 . The positive value of the estimate indicates that the higher the Leadership Commitment, the more likely it is to improve the Quality of Financial Statements of ministries and institutions. Research results in line with Agung, Tut Madiguna dan Gayatri (2018); Lubis and Saripudin (2017) ; Yusnita (2017); Fitriani (2017), shows that Leadership Commitment has a significant impact on the Quality of Financial Statements.

Information Technology Support (X3) on Quality of Financial Statements of Ministries and Institutions $(\mathrm{Y})$ produces a T statistical value $1.14<$ T-table 1.96 with the estimated value indicated positive, which is 0.13. Information Technology Support has a positive and insignificant effect on the Quality of Financial Statements of ministries and institutions. Information Technology Support does not necessarily improve the quality of Financial Statements of ministries and institutions. The research is not in line with Rasyidah and Hasyim (2017); Agung, Tut Madiguna dan Gayatri (2018); Yusnita (2017) ; Aryani (2013); Winidyaningrum (2010). that information technology utilization influenced to the quality of financial statements. 
The results of previous research differed because of differences in respondents and accounting systems that do not provide automatic accrual adjustments. It is necessary to make accrual adjustments so that it is necessary for human resources to understand accounting and transfer information accrual.

Internal Control over Financial Reporting (X4) on Quality of Financial Statements of Ministries and Institutions (Y) produces a T statistical value 2.30 $>$ T-table 1.96 with the estimated value indicated as positive, which is 0.14 . The positive value of the estimate indicates that the higher internal control over financial reporting is likely to improve the quality of financial statements of ministries and institutions. Research results in line with Karsana (2017) ; Agung, Tut Madiguna and Gayatri (2018), Yusnita (2017) ;)Fitriani (2017), ; Agustiawan and Ni (2016); Christianti, Dianne Natalia (2013); Mardiana, Rizki and Heru Fahlevi (2017); Lashgari et al. (2015); Fransiska et al.(2015) ; Aryani (2013) showed that the internal control system has an influence on the quality of financial statements.

HR Competency (X1), Leadership Commitment (X2), Technology Support (X3), Internal Control over Kuangan Reporting together (X4) on Quality of Financial Statements of Ministries and Institutions (Y) produces F statistical value 58,86 > T-table 2.42 with the estimated value indicated as positive. The value of the positive value estimates indicates that the higher the Human Resources Competency, Leadership Commitment, Information Technology Support, Internal Control over Financial Reporting together, it tends to improve the Quality of Financial Statements of ministries and institutions. Research results align with Karsana (2017) that human resources competence and internal control system positively affect the quality of financial statements. Agung, Tut Madiguna, and Gayatri research (2018) that leadership style, human resource competence, internal control system, organizational commitment, and information technology utilization significantly impact financial statements' quality. Research agustiawan, Nyoman Triyadi, and Ni Ketut Rasmini (2016) apply accrual-based accounting systems, information technology, and internal control system positively to the Quality of Financial Statements.

Implementation of Accrual-Based Government Accounting Standards (Z) on Quality of Financial Statements of Ministries and Institutions (Y) produces a T statistical value 4,15 > T-table 1.96 with the estimated value indicated as positive, which is 0.35 . The positive value of estimates indicates that the higher the Implementation of Accrual-Based Government Accounting Standards, the more likely it is to improve the Quality of Financial Statements of ministries and institutions. Accrual-based government accounting also allows the government to identify opportunities to use future resources and realize good management. Research results in line with Najati et al. (2016),; Karsana (2017) ; Yusnita (2017) ; Agustiawan, Nyoman Triyadi and Ni Ketut Rasmini (2016); Christianti, Dianne Natalia (2013); Mardiana, Rizki and Heru Fahlevi (2017); Aryani (2013); Kristyono et al.(2013) that the Implementation of Accrual-based Government Accounting Stansar affects the quality of financial statements.

HR Competency (X1), Leadership Commitment (X2), Technology Support (X3), Internal Control over Financial Reporting together (X4) Implementation of Accrual-Based Government Accounting Standards (Z) on Quality of financial Statements of Ministries and institutions (Y) produces F statistical value 60,04 > 
T-table 2,263 with the estimated value indicated as positive. The positive value of estimates shows that the higher hr competencies, leadership commitments, information technology support, internal control over financial reporting, and implementation of accrual-based accounting systems tend to improve the quality of financial statements of ministries and institutions. The research results are in line with Budiman, Slamet (2016), Sari, Rissa Paramita (2017) Agung, Tut Madiguna and Gayatri (2018), Karsana (2017) . The research results Budiman, Slamet (2016), Yogiswara, I Wayan Gede Farma Putra and Ariyanto (2015). Commitment of agency leaders has a positive and significant influence on the successful implementation of accrual-based local government financial statements. The results of Eriotis et al. (2011) showed a positive and significant relationship between IT Quality and successful adoption of Accrual Accounting reforms. Based on the research results conducted by Lashgari, Zahra et al. (2015), Accrual quality can be attributed to internal control weaknesses that can affect financial operations and financial reporting. Companies with weak internal control over financial reporting generally have lower accrual quality, and Accrual quality is closely related to internal control weaknesses. Christianti Research Results, Dianne Natalia (2013) Najati, Ida et al (2016), Agustiawan, Nyoman Triyadi and Ni Ketut Rasmini (2016), Karsana (2017) Mardiana, Rizki and Heru Fahlevi (2017) that the implementation of accrual-based accouting affects the quality of financial statements.

\section{REFERENCES}

Agung, Tut Madiguna dan Gayatri, (2018) "Analisis Faktor-Faktor yang Mempengaruhi Kualitas Laporan Keuangan Pemerintah Daerah Kabupaten Karangasem" E-Jurnal Akuntansi Universitas Udayana ISSN : 2302-8556 Vol.23.2. Mei pp 1253-1276 Retrieved from https://doi.org/10.24843/EJA.2018.v23.i02.p17

Agustiawan, Nyoman Triyadi dan Ni Ketut Rasmini, (2016) "Pengaruh Sistem Berbasis Akrual, TI, dan SPIP Pada Kualitas Laporan Keuangan Dengan Kompetensi SDM Sebagai Moderasi" Jurnal Ekonomi dan Bisnis Universitas Udayana ISSN : 2337-3067, Vol. 5.10 pp 3475-3500

Aryani. (2013), "Analisis Faktor-Faktor Yang Mempengaruhi Kualitas Laporan Keuangan Kementerian Negara/Lembaga Satuan Kerja Mitra KPPN Medan II. Medan : Pascasarjana Universitas Sumatera Utara. Retrieved from https://repositori.usu.ac.id/handle/123456789/34335

Christanti, Dianne Natalia. (2013) "Pengaruh Akuntansi Berbasis Akrual Dan Sistem Pengendalian Intern Terhadap Kualitas Laporan Keuangan (Survey Pada Biro Keuangan Setda Pemerintah Provinsi Jawa Barat)" Jurnal Fakultas Ekonomi Universitas Komputer Indonesia Retrieved from https://elib.unikom.ac.id/files/disk1/636/jbptunikompp-gdl-diannenata31791-12-unikom-2-l.pdf

Eriotis, Nikolaos, Filippos Stamatiadis and Dimitrios Vasiliou. (2011) "Assessing Accrual Accounting Reform in Greek Public Hospitals: An Empirical Investigation, International Journal of Economic Sciences and Applied

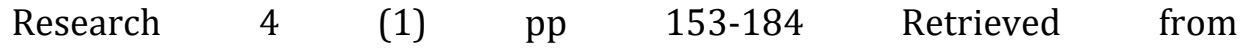
https://doi.org/10.2139/ssrn.1978671

Evita Puspitasari, Sri Mulyani, Devianti Yunita H, (2016) "Faktor-Faktor Penentu Keberhasilan Penerapan Akuntansi Berbasis Akrual Di Pemerintah Daerah" Forum Keuangan dan Bisnis V ISBN : 978-602-17225-6- pp. 110-119 
Fitriani, Asri. (2017), " Pengaruh Komitmen Pimpinan Dan Lingkungan Pengendalian Internal Terhadap Kualitas Laporan Keuangan (Survei Pada Skpd Provinsi Sulawesi Tengah)" Jurnal Katalogis ISSN : 2302-2019, Volume 5 Nomor 4, April pp113-122

Fransiska, Neco, Aris Eddy Sarwono, Dewi Saptantinah Puji Astuti. (2015) "Sistem Pengendalian Intern Dan Kualitas Laporan Keuangan Pemerintah Daerah Di Indonesia" Syariah Paper Accounting FEB UMS ISSN 2460-0784 pp 323-331

Herwiyanti, Eliada, Sukirman, Fairuz Sufi Aziz, (2017) " Analisis Implementasi Akuntansi Berbasis Akrual pada Inspektorat Jenderal Kementerian Keuangan" Jurnal Akuntansi dan Keuangan ISSN 2338-8137, Vol. 19, No. 1, Mei pp 11-23 Retrieved from https://doi.org/10.9744/jak.19.1.13-23

Irawan, E. (2015). Tantangan Keberhasilan Penerapan Akuntansi Berbasis Akrual fenomena magelang

Karsana, I Wayan dan I Gusti Ngurah Agung Suaryana. (2017) "Pengaruh Efektivitas Penerapan SSAP, Kompetensi SDM, Dan SPI Pada Kualitas Laporan Keuangan Pemerintah Kabupaten Bangli", E-Jurnal Akuntansi Universitas Udayana ISSN : 2302-8556 Vol.21.1. Oktober pp. 643-670

Kisworo, J. ; Shauki, E. (2019) Teori Institusional Dalam Penyusunan Dan Publikasi Laporan Tahunan Sektor Publik (Studi Kasus Pada Kementerian Dan Lembaga Negara Di Indonesia). Indonesian Treasury Review: Jurnal Perbendaharaan, Keuangan Negara dan Kebijakan Publik, 4, 305-321. Retrieved from https://doi.org/10.33105/itrev.v4i4.157

Kristyono, J., Raharjo, K., and Andini, R. (2013). Faktor yang Mempengaruhi Keberhasilan Pelaksanaan Keuangan Daerah sesuai PP 71 / 2010 (Studi pada Dinas Pendidikan Kota Semarang Tahun 2012/2013). Sosio Eko Tekno : Jurnal Ilmiah Mahasiswa Universitas Pandanaran

Kusuma, Muhamad Indra Yudha dan Fuad. (2013) "Analisis Faktor-Faktor Yang Mempengaruhi Tingkat Penerapan Akuntansi Akrual Pada Pemerintah", Jurnal Akuntansi Universitas Diponegoro, Vol. 2 No.3 pp1-13 Retrieved from https://www.neliti.com/publications/253189/analisis-faktor-faktor-yangmempengaruhi-tingkat-penerapan-akuntansi-akrual-pada

Lashgari, Gawradar, bakhshayesh, (2015) "Internal Control Weakness and Accruals Quality in Companie Listed on Tehran Stock Exchange" Procedia - Social and Behavioral Sciences 207 (2015) 454 - 461 Retrieved from https://doi.org/10.1016/j.sbspro.2015.10.115

Lubis, Irsan Dan Saripudin. (2017) " Pengaruh Kompetensi Akuntansi, Komitmen Dan Mutasi Terhadap Kualitas Laporan Keuangan Pemerintah Daerah: Komitmen Pimpinan Sebagai Moderating" Jurnal Ilmiah widya ISSN 23376686 Volume 4 Nomor 2308 Agustus desember pp 302-308

Mariana, Rizki dan Heru Fahlevi, (2017) "Pengaruh Pemahaman Akuntansi, Pengendalian Internal Dan Efektivitas Penerapan SAP Berbasis Akrual Terhadap Kualitas Laporan Keuangan (Studi Pada Satuan Perangkat Kerja Kota Banda Aceh), Jurnal Ilmiah Mahasiswa Ekonomi Akuntansi (JIMEKA) Vol. 2, No. 2 pp 30-38

Najati, Ida, Endar Pituringsih. Animah, (2016), "Implementasi Akuntansi Berbasis Akrual: Pengujian Determinan Dan Implikasinya Terhadap Kualitas Laporan Keuangan Kementerian/Lembaga" Jurnal Akuntansi Universitas Jember, Vol. 14 No. 1 Retrieved from https://doi.org/10.19184/jauj.v14i1.2501 
Nufus, K. (2014). Faktor-faktor yang Mempengaruhi Penerapan Standar Akuntansi Pemerintah pada Pemerintah Kota Baubau. Jurnal Liquidity Vol. 3, No. 1, pp. 11-18. Retrieved from https://doi.org/10.32546/lq.v3i1.99

Pamungkas, Bambang (2012). " Pengaruh penerapan Akuntansi Sektor Publik dan Pengawasan terhadap Kualitas Laporan Keuangan dan implikasinya terhadap Akuntabilitas Kinerja Instansi Pemerintah." Jurnal Ilmiah Ranggagading, Vol 12 No. 2, Oktober 2012 : 82-93 Retrieved from https://jurnal.stiekesatuan.ac.id/index.php/jir/article/view/57

Pattiasina, Victor dan Muhamad Yamin Noch (2019), " Implementasi Akuntansi Berbasis Akrual Ditinjau Dari Sisi Sumber Daya Manusia, Pemanfaatan Teknologi Informasi Dan Sistim Pengendalian Intern" Accounting Journal Universitas Yapis Papua : Volume 1 Nomor 1 Desember 2019.

Peraturan Menteri Keuangan Nomor 225/PMK.05/ (2016) Tentang Penerapan Standar Akuntansi Pemerintahan Berbasis Akrual Pada Pemerintah Pusat.

Peraturan Pemerintah Republik Indonesia Nomor 71 Tahun (2010) tentang Standar Akuntansi Pemerintahan

Puspitarini dkk, (2017). "Pengaruh Kompetensi Sumber Daya Manusia Dan Teknologi Informasi Terhadap Penerapan Akuntansi Berbasis Akrual Pada Pengelolaan Barang Milik Negara" Journal Of Applied Managerial Accounting Vol. 1, No. 2, 2017, 141-149 ISSN : 2548-9917 Retrieved from https://doi.org/10.30871/jama.v1i2.501

Putra, I.W.G.Y.D. and Ariyanto, D. (2015). Faktor-faktor yang Mempengaruhi Penerapan Standar Akuntansi Pemerintahan Berbasis Akrual. E-Jurnal Akuntansi Universitas Udayana 13.1: 14-32.

Rasyidah, Nadir dan Hasyim. (2017). Pengaruh Pemanfaatan Teknologi Informasi,

Rivai Zainal, Veithzal dkk, (2014), Kepemimpinan dan Perilaku Organisasi, Raja Grafindo Persada, Jakarta.

Rivai, Veithzaldan Sagala,Ella Jauvani. (2010). Manajemen Sumber Daya Manusia untuk Perusahaan dari Teori ke Praktik. Jakarta : PT Raja Grafindo.

Sari, (2017) Rissa Paramita Rissa Paramita. Pengaruh Komunikasi, Kompetensi Sumberdaya Manusia, Struktur Birokrasi, Dan Gaya Kepemimpinan Terhadap Implementasi Standar Akuntansi Pemerintah Basis Akrual (Studi Empiris Pada Pemerintah Daerah Kota Bukittinggi), Skripsi Program Sarjana Universitas Negeri Padang

Slamet, Budiman. (2016), "Faktor-Faktor Yang Mempengaruhi Keberhasilan Penerapan Akuntansi Pemerintah Berbasis Akrual (Studi Kasus Pada Pemerintah Kota Bekasi)" Jurnal Ilmiah Akuntansi Fakultas Ekonomi E-ISSN 2502-4159, Vol. 2 No.2 pp 1-15 Retrieved from https://doi.org/10.34204/jiafe.v2i2.540

Sukadana, I.C. and Mimba, N.P.S.H. (2015). Pengaruh Kualitas Sumber Daya Manusia terhadap Kesiapan Penerapan SAP Berbasis Akrual pada Satuan Kerja Wilayah Kerja KPPN Denpasar. E-Jurnal Akuntansi Universitas Udayana 12.1: 35-49.

Surya, I Gusti Bagus dan Kencana. (2015), Toward Implementation of Accrual Basis in Indonesia Government: Key Success Factors. GSTF Journal on Business Review (GBR) Vol. 4, No. 1. Retrieved from https://doi.org/10.7603/s40706-015-0007-4

Waspodo Lego, Dona Primasari, Indayani. (2017) "Anteseden dan Konsekuensi Implementasi Sistem Akrual Basis (Studi Empiris pada Satuan Kerja 
Perangkat Daerah Provinsi Lampung)" Journal of Accounting Research and Review ISSN 1693-3397 Vol. 10 NO. 1, Januari 2017 pp 25-36

Winidyaningrum, Celviana dan Rahmawati. (2010). "Pengaruh Sumber Daya Manusia Dan Pemanfaatan Teknologi Informasi Terhadap Keterandalan Dan Ketepatwaktuan Pelaporan Keuangan Pemerintah Daerah Dengan Variabel Intervening Pengendalian Intern Akuntansi (Studi Empiris di Pemda SUBOSUKAWONOSRATEN)". SNA 13 Purwokerto

Yusnita, (2017) Tengku Erna. Analisis Faktor-Faktor Yang Mempengaruhi Kualitas Laporan Keuangan Pemerintah Kabupaten Langkat Dengan Komitmen Pimpinan Sebagai Variabel Moderating, Tesis Program Magister Akuntansi Universitas Sumatera Utara 